\title{
A Case of Nontuberculous Mycobacterial Infection on Branchial Cleft Cyst
}

\author{
Yu Jin Go, Sohl Park, Han Su Kim ${ }^{\mathbb{D}}$, and Soo Yeon Jung ${ }^{\mathbb{D}}$ \\ Department of Otorhinolaryngology-Head and Neck Surgery, College of Medicine, Ewha Womans University, Seoul, Korea
}

새열기형에서 발생한 비결핵성 항산균 감염 1 예

고유진 · 박 솔 · 김한수 · 정수연

이화여자대학교 의과대학 이비인후-두경부외과학교실

\author{
Received February 9, 2021 \\ Revised April 12,2021 \\ Accepted April 14, 2021 \\ Address for correspondence \\ Soo Yeon Jung, MD, PhD \\ Department of Otorhinolaryngology- \\ Head and Neck Surgery, \\ College of Medicine, \\ Ewha Womans University, \\ 1071 Anyangcheon-ro, \\ Yangcheon-gu, Seoul 07985, Korea \\ Tel $+82-2-2650-5832$ \\ Fax $+82-2-2648-5604$ \\ E-mail mdjungsy@ewha.ac.kr
}

\begin{abstract}
Nontuberculous mycobacteria (NTM) is commonly found in the surrounding environment and can cause opportunistic infection. Mainly, it causes lymph node infection in the cervical area, which is often known to occur in children. Recently, we have experienced a case of NTM infection on a branchial cleft cyst in a 36-year old male. NTM was diagnosed by fine needle aspiration and branchial cleft cyst was confirmed by postoperative pathologic findings. We report this case with a review of literature.
\end{abstract}

Korean J Otorhinolaryngol-Head Neck Surg 2021;64(7):522-5

Key Words Adult · Branchial cleft cyst · Nontubeculous mycobacteria.

\section{서 론}

비결핵성 항산균은 토양, 물, 동물의 배설물 및 사람의 인 두 분비물을 포함한 환경에 흔히 존재하는 상재균이다. ${ }^{1)}$ 비결 핵성 항산균의 두경부 감염은 대부분 경부 림프절 감염이 흔 하며, 주로 소아에서 흔히 발생하는 것으로 알려져 있다. 비결 핵성 항산균 림프절 감염의 주치료는 수술적 절제술이며, 수 술적 절제술은 배액, 긁어냄술(curettage), 흡인(aspiration)과 같은 시술에 비하여 재발률이 낮다고 알려져 있다. ${ }^{2)}$ 항생제 치료는 수술적 절제술 전에 사용하거나 혹은 보조적인 치료 로서 사용될 수 있다. ${ }^{3)}$ 비결행성 항산균의 경부 감염은 주로 림프절에서 발생하며 드물게 소아의 3형 새열기형낭종에서 발생이 보고되어 있으나 ${ }^{2,4)}$ 성인에서의 2형 새열기형낭종에서

This is an Open Access article distributed under the terms of the Creative Commons Attribution Non-Commercial License (https://creativecommons.org/licenses/by-nc/4.0) which permits unrestricted non-commercial use, distribution, and reproduction in any medium, provided the original work is properly cited.
의 발생은 현재까지 보고된 바 없다. 본 증례에서는 2형 새열 기형낭종에 발생한 비결핵성 항산균 감염 1 예를 국내 문헌 고찰과 함께 보고하는 바이다.

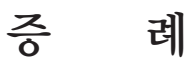

36세 남자 환자가 내원 4일 전부터 지속된 우측 경부의 통 증과 발열로 본원 응급실에 내원하였다. 내원 당시 시행한 신 체 검진에서 우측 측경부의 부종과 함께 동통, 발적, 열감이 동반되어 있었고, 응급실에 시행한 경부 전산화단층촬영 검 사에서 $6 \times 5.3 \mathrm{~cm}$ 크기의 낭종성 종괴가 확인되었다(Fig. 1A). 후두 내시경상에서 샛길은 확인되지 않았으며, 경부 초음파 검사상 우측 흥쇄유돌근 하방의 거대한 낭종성 종괴가 확인 되었다. 초음파 및 경부 전산화단층촬영 검사에서 제 2형 새 열기형낭종의 감염이 의심되어 초음파 유도하 세침흡인검사 를 시행하였으며, 화농성의 액체 $25 \mathrm{cc}$ 가 배액되었다. 세균배 
양검사 및 항산균 도말검사를 시행하였으며 결핵균 핵산증폭 검사 결과 비결핵성 항산균 양성 소견 확인되었고, 감염내과 협의 진료하에 경험적 항생제인 clarithromycin, amikacin과 imipenem의 경정맥 주입 치료를 시작하였다. 배농 이후에 종 창 및 통증이 지속되어 배농 및 증상 경감을 위한 초음파 유 도하 세침흡인을 추가 시행하였으며, 염증 수치 호전 후 전신 마취하에 경부 낭종 절제술을 시행하였다. 수술 중 주변 조직 과의 심한 유착이 확인되었고 낭종 절제 후에는 수술 부위를 amikacin으로 세척을 시행하여 수술을 마쳤다. 병리조직검 사상 낭종의 벽은 중층편평상피세포로 이루어져 있어 새열기 형낭종에 합당한 소견을 보였으며 림프절을 시사하는 소견은 보이지 않았다. 고배율 $(\times 200)$ 에서 낭종은 중성구를 포함한 염증세포 및 괴사조직과 이물거대세포의 집합체가 함께 보이
고 있어 새열기형낭종을 최종 진단하였다(Fig. 2).

환자는 수술 후 3일째에 퇴원하면서 경험적 경구 항생제로 clarithromycin, rifampicin과 ethambutol을 18일간 유지하 였고, 수술 12 일 뒤 추적 관찰을 위해 시행한 경부 전산화단 층촬영에서 낭종의 완전한 제거와 함께 주위 조직의 염증호 전을 확인할 수 있었다(Fig. 1B). 본 증례에서 동정된 nontuberculous mycobacteria(NTM)은 Mycobacterium abscessus 로 속효성장균에 해당하나 균검사 시행 6주 후에 균의 종류 가 확인되었으며, 항생제 감수성 결과 사용했던 경험적 경구 항생제에 내성이 보고되어 감염내과로 재 입원 후 정맥항생 제로 amikacin과 cefoxitin을 4주간 유지, 퇴원 이후 경구 항 생제로 linezolid와 clofazimine을 8주간 유지한 뒤 치료를 종결하였다.
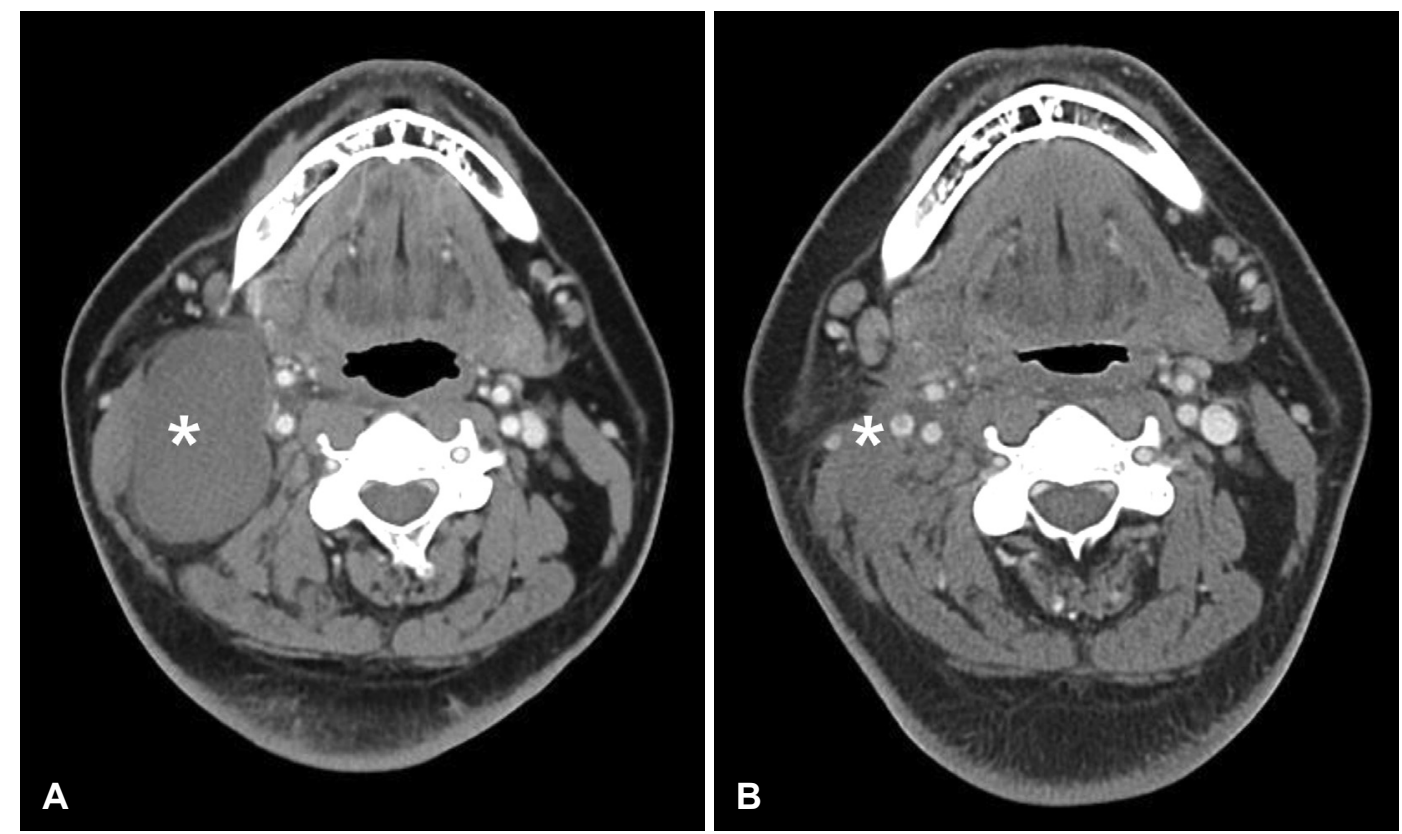

Fig. 1. Pre and Postoperative CT image. $6 \mathrm{~cm}$-sized mass in peripheral thin rim-enhancing low density cystic lesion (asterisk) in the right neck level II on axial CT images (A). On postoperative day 50, residual postoperative fluid collection was not observed at previous cystic lesion site (asterisk) and improvement of adjacent cellulitis at right neck level II on axial CT images (B).
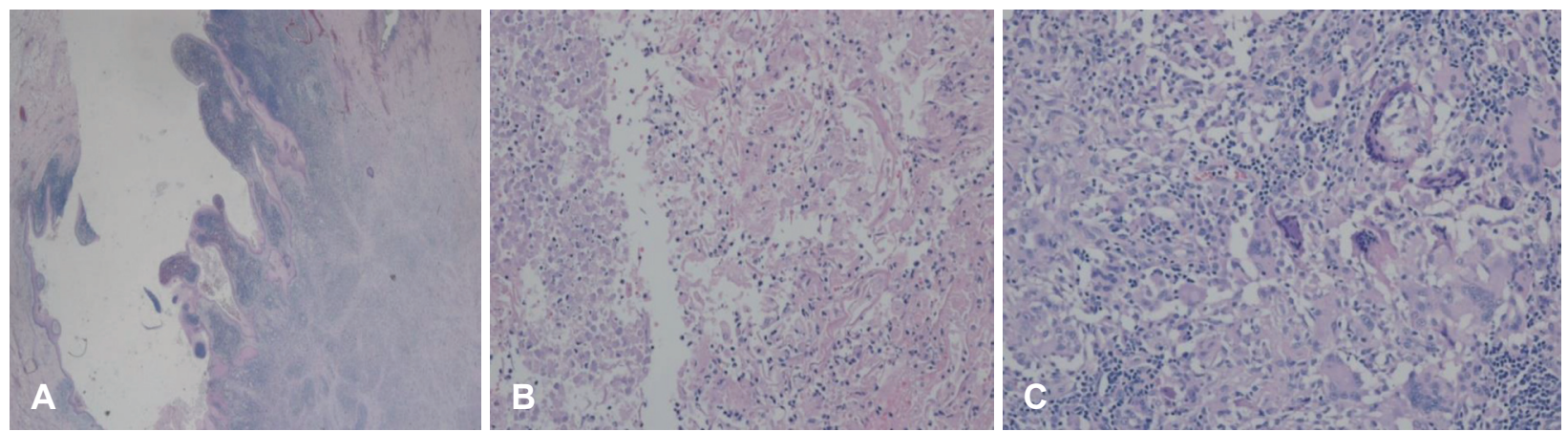

Fig. 2. Histopathologic findings. The cyst was lined with stratified squamous epithelium. The cyst wall in fibrotic wall including lymphoid follicle (H\&E stain, $\times 40)(A)$. Higher magnification shows inflammatory cells including neutrophil and necrotic material $(H \& E$ stain, $\times 200)$ $(B)$, Foreign body type giant cells aggregation $(H \& E$ stain, $\times 200)(C)$. H\&E: hematoxylin and eosin. 


\section{고 찰}

비결핵성 항산균은 사람의 인두 분비물에 흔히 존재하는 상재균으로서 비결핵성 항산균의 경부 감염은 대부분은 소 아에서 보고된다. 이는 소아의 구강 점막이 치아의 맹출이나 외상에 의하여 손상된 후 구강 내에 상재하던 비결핵성 항산 균에 의해 감염되는 것으로 생각된다. ${ }^{5)}$ 비결핵성 경부림프절 감염의 치료로는 수술, 항결핵제, 절개배농이나 세침흡인, 소 파술이 시도되어왔으나 재수술률과 재발률을 낮추는 수술적 절제술이 가장 효과적인 것으로 알려져 있다. ${ }^{2)}$ 절개배농술은 1990년대 초에 주로 시행되었으나 절개배농술을 받은 환자 들의 다수가 2 차 수술이 필요로 하였고, 이에 절개배농술은 추천되지 않는 방법이다. ${ }^{6}$

새열기형은 태생기 2주경 발생하여 태생 6 7주경 분화를 마치는 새성기관(branchial apparatus)이 불완전 폐쇄되어 발 생한다. 그 중 제 2 새열기형은 가장 흔한 형태의 새열기형이며 인두 혹은 피부로의 연결 여부에 따라 낭종(cyst), 동(sinus), 누공(fistula)의 형태로 구분된다.) 제2 새열기형은 일반적으 로 흥쇄유돌근 상부 $1 / 3$ 부위 전방에 무통성의 종괴로 나타 나거나 호흡기계 감염과 동반되어 크기가 증가하여 발견되기 도 한다. ${ }^{8}$ 제2 새열기형은 림프절염, 전이성 림프절, 신경성 종 양, 경동맥구 종양 등과의 감별이 필요하며 이 경우 세침으로 종괴를 흡입하는 것이 진단에 도움이 된다. ${ }^{9}$ 국외에 제3 새열 기형에 감염된 비결핵성 항산균 감염이 1 예 보고된 바 있으 며, 이 경우에는 세침흡인 및 항생제를 사용하여 초치료를 하 였고, 수술적 절제술을 시행하였으나 3주 뒤 샛길의 재발로 인하여 절개 배농술을 추가적으로 시행하였고 6개월간의 항 결핵제 치료를 진행하였다. ${ }^{4)}$ 본 증례에서는 절개 배농술이 아 닌 초기에 세침흡인술을 통해 NTM 감염을 진단 후 수술적 적출술을 시행하였기에 완치 확률을 높일 수 있었다.

연부조직의 비결핵성 항산균 감염의 경우 속효성장균에 의 한 감염인 경우가 지연성장균에 의한 감염에 비해 더 흔하다 고 알려져 있어, 본 증례에서도 속효성장균 감염 의심하에 경 험적 항생제인 clarithromycin, imipenem, amikacin으로 치 료를 시작하였으나 7일 이상이 지나도 균 동정이 되지 않아 지연성장균 감염을 염두하여 항생제를 clarithromycin, rifampin, ethambutol로 변경하여 치료를 지속하였다. ${ }^{10)}$ 이후 마크로라이드 계열 항생제에 내성이 있는 Mycobacterium abscessus 임이 확인되어 amikacin 및 cefoxitin으로 항생제 를 변경하였으며, 경구 약제로 변경하여 linezolid, clofazimine을 8주간 투여하였다. 실제로 Mycobacterium abscessus의 경우 마크로라이드 내성 균주인 경우가 흔하여 항생제 내성 검사에 따른 적절한 항생제의 선택이 필요하다. 항생제
치료기간에 대하여 아직까지 정립된 바는 없으나 경과에 따 라 4 6개월까지 치료해 볼 수 있다고 알려져 있다. 본 증례에 서와 같이 농양 형성이 동반되거나 질병의 범위가 광범위한 경우 수술적 치료를 병행해 볼 수 있다고 알려져 있다. ${ }^{10,11}$

본 증례에서는 감염으로 인한 경부 종창의 초기 접근에서 두경부 단층촬영 및 초음파에서 림프절 기원이 아닌 2형 새 열기형낭종 기원의 감염을 의심하였으며 초기 절개배농이 아 닌 세침흡인검사를 통해 비결핵성 항산균 감염의 진단이 가 능하였다. 이에 경험적 항생제와 반복적인 세침흡인으로 초기 치료를 시행하였고, 이후 완전한 수술적 절제술을 통해 완치 가능성을 높일 수 있었다. 수술 후 조직검사 결과를 통해 새 열기형에 감염된 비결핵성 항산균임을 확진할 수 있으며 감 염내과 협의진료하에 경정맥 및 경구 항생제를 총 18 주간 유 지 후 치료를 종결하였고 7개월이 경과한 현재까지 재발하지 않았다. 비결핵성 항상균은 항생제 내성이 높고 특히 본 증례 와 같이 정확한 균동정 및 항생제 감수성 검사까지 4 6주 가량이 소요되는 경우, 정확한 항생제 투여 가능 전 적절한 배농 및 수술적 적출 시기의 결정이 환자의 치료에 매우 중요 하다. 특히 성인에서 매우 드물게 나타나며 특히 새열기형으 로의 감염은 국내에서는 보고된 바가 없어 치료 초기에 의심 하기가 어려워 잘못된 치료를 시행할 수 있다. 이에 새열기형 낭종의 감염 시 $\mathrm{NTM}$ 의 존재 가능성을 고려해 볼 필요성이 있어 문헌 고찰과 함께 보고하는 바이다.

\section{Acknowledgments}

None.

\section{Author Contribution}

Conceptualization: Soo Yeon Jung. Data curation: Yu Jin Go. Investigation: Yu Jin Go, Sohl Park. Methodology: Yu Jin Go. Supervision: Soo Yeon Jung, Han Su Kim. Validation: Soo Yeon Jung. Visualization: Yu Jin Go, Soo Yeon Jung. Writing —original draft: Yu Jin Go. Writing — review \& editing: Soo Yeon Jung.

\section{ORCIDs}

Soo Yeon Jung ～https://orcid.org/0000-0001-7497-3057 Han Su Kim https://orcid.org/0000-0003-2239-0225

\section{REFERENCES}

1) Moerman M, Dierick J, Mestdagh J, Boedts D, Van Cauwenberge P. Mastoiditis caused by atypical mycobacteria. Int J Pediatr Otorhinolaryngol 1993;28(1):69-76.

2) Albright JT, Pransky SM. Nontuberculous mycobacterial infections of the head and neck. Pediatr Clin North Am 2003;50(2):503-14.

3) Luong A, McClay JE, Jafri HS, Brown O. Antibiotic therapy for nontuberculous mycobacterial cervicofacial lymphadenitis. Laryngoscope 2005;115(10):1746-51.

4) Ferzli GS, Thakkar P, Goldstein NA, Chernichenko N. Third branchial cleft cyst with mycobacterium infection. OTO Open 2017;1(2):2473974X17705832. 
5) Holland AJ, Holland J, Martin HC, Cummins G, Cooke-Yarborough C, Cass DT. Noncervicofacial atypical mycobacterial lymphadenitis in childhood. J Pediatr Surg 2001;36(9):1337-40.

6) Panesar J, Higgins K, Daya H, Forte V, Allen U. Nontuberculous mycobacterial cervical adenitis: A ten-year retrospective review. Laryngoscope 2003;113(1):149-54.

7) Edgerton MT, Hiebert JM. Vascular and lymphatic tumors in infancy, childhood and adulthood: Challenge of diagnosis and treatment. Curr Probl Cancer 1978;2(7):1-44.

8) Acierno SP, Waldhausen JHT. Congenital cervical cysts, sinuses and fistulae. Otolaryngol Clin North Am 2007;40(1):161-76.

9) Gibson WS Jr, Fenton NA. Congenital sublingual dermoid cyst. Arch Otolaryngol 1982;108(11):745-8.

10) Wi YM. Treatment of extrapulmonary nontuberculous mycobacterial diseases. Infect Chemother 2019;51(3):245-55.

11) Griffith DE, Aksamit T, Brown-Elliott BA, Catanzaro A, Daley $C$, Gordin F, et al. An official ATS/IDSA statement: Diagnosis, treatment, and prevention of nontuberculous mycobacterial diseases. Am J Respir Crit Care Med 2007;175(4):367-416. 